Wioletta Kilar, Sławomir Kurek, Tomasz Rachwal

Uniwersytet Pedagogiczny

im. Komisji Edukacji Narodowej

w Krakowie

\title{
Kształtowanie kompetencji osobistych i społecznych w szkolnictwie zawodowym dla sektora handlu detalicznego w świetle opinii partnerów społecznych
}

\author{
Developing personal and social competencies in vocational training \\ for the retail sector in the opinions of social partners
}

\begin{abstract}
Streszczenie
Celem artykułu jest przedstawienie roli kompetencji osobistych i społecznych jako składowych postawy przedsiębiorczej w warunkach kryzysu gospodarczego, którego jednym z przejawów jest wzrastające, głównie wśród ludzi młodych, bezrobocie. Szczególna uwaga zostanie skierowana na kształcenie tych kompetencji w szkolnictwie zawodowym, przygotowującym do pracy w sektorze handlu detalicznego na podstawie celów i założeń międzynarodowego projektu badawczo-edukacyjnego „Kompetencje Sektora Handlu Detalicznego - kształtowanie kompetencji osobistych i społecznych w szkolnictwie zawodowym dla sektora handlu detalicznego (ReSeCo)". W artykule przedstawiono także ważniejsze wnioski z analizy opinii partnerów społecznych odnośnie potrzeb i wymagań w sektorze sprzedaży detalicznej w zakresie rozwijania kompetencji osobistych i społecznych oraz przydatności proponowanych materiałów dydaktycznych.
\end{abstract}

\begin{abstract}
This article aims to present the role of social and self-competencies, as a part of entrepreneurial attitudes in the conditions of economic crisis, which is one of the symptoms of rising unemployment, especially among young people. Particular attention will be paid to the training of these competencies in the course of vocational education, preparing for work in the retail sector, based on the goals and objectives of international research and the educational project: 'Retail Sector Competencies: Developing self- and social competencies in vocational training for the retail sector (ReSeCo)'. This article presents major findings from the analysis of the social partner opinions, concerning the needs and requirements in the retail sector, to develop social and self-competencies and suitability of the proposed teaching materials.
\end{abstract}

Słowa kluczowe: kompetencje osobiste i społeczne; partnerzy społeczni; sektor handlu detalicznego; szkolnictwo zawodowe

Key words: personal and social competencies; social partners; retail sector; vocational education 


\section{Wprowadzenie}

Choć współczesny okres dekoniunktury gospodarczej, określany powszechnie mianem światowego kryzysu, dotyka w różnym stopniu poszczególne działy gospodarki w sektorze rolniczym, przemysłowym oraz usługowym, to jednak wbrew powszechnym, nagłośnionym medialnie opiniom o depresji gospodarczej porównywalnej z Wielkim Kryzysem przełomu lat 20. i 30. XX w. jego wpływ na przemiany struktur gospodarczych, funkcjonowanie wielu rodzajów działalności, stref ekonomicznych, jak i poszczególnych korporacji jest ograniczony (m.in. Czapliński, 2011; Dorocki, 2011; Kitowski, 2009; 2011; Rachwał, 2011; Rachwał, Zdon-Korzeniowska, 2011; Rettinger, Staszak, 2011; Uliszak, 2011; Wójtowicz, 2011; Zioło, 2011). Nie zmienia to faktu, że - jak stwierdzili T. Rachwał i M. Zdon-Korzeniowska (2011) na podstawie badań własnych i prac innych autorów - gospodarka światowa wkroczyła w erę turbulencji, gdzie sytuacja społeczno-ekonomiczna staje się nie tylko niestabilna, ale także trudno przewidywalna. Te turbulencje i ograniczone możliwości skutecznego przewidywania dalszych tendencji przemian stają się nową rzeczywistością. W tej sytuacji w szczególnie trudnym położeniu znajduje się pojedynczy człowiek, dla którego te burzliwe fluktuacje społeczno-gospodarcze oznaczają niepewność w zakresie możliwości dalszego zatrudnienia bądź znalezienia pracy w przypadku jej braku, utrzymania dobrego poziomu życia, budowania skutecznych strategii finansowych zarówno w odniesieniu do budżetu domowego, jak i firmy, której jest właścicielem lub w której pracuje. Niezwykle istotne w tej sytuacji są jego kompetencje osobiste i społeczne, związane z postawą przedsiębiorczą, dzięki którym łatwiej będzie się mu odnaleźć w warunkach niepewnej, nieprzewidywalnej i trudnej sytuacji gospodarczej.

W nawiązaniu do zarysowanych przesłanek celem artykułu jest więc przedstawienie roli kompetencji osobistych i społecznych jako składowych postawy przedsiębiorczej w warunkach dekoniunktury gospodarczej. Szczególna uwaga została zwrócona na kształcenie tych kompetencji w szkolnictwie zawodowym, przygotowującym do pracy w sektorze handlu detalicznego na podstawie celów i założeń międzynarodowego projektu badawczo-edukacyjnego „Kompetencje Sektora Handlu Detalicznego - kształtowanie kompetencji osobistych i społecznych w szkolnictwie zawodowym dla sektora handlu detalicznego (ReSeCo)". Projekt ten, wspólfinansowany ze środków UE w ramach Lifelong Learning Programme (subprogram: Leonardo da Vinci, kategoria działania: Projekty wielostronne, działanie: Transfer innowacji), był realizowany w okresie 1.10.2011-30.09.2013 przez zespół naukowców reprezentujących uniwersytety z czterech krajów partnerskich: Niemiec (Uniwersytet w Kolonii, lider projektu), Polski (Uniwersytet Pedagogiczny w Krakowie), Wielkiej Brytanii (Uniwersytet w Southampton, w pierwszym roku realizacji Uniwersytet Westminster w Londynie) oraz Włoch (Uniwersytet w Bergamo). W projekcie więli też udział nauczyciele i uczniowie szkół ponadgimnazjalnych (zawodowych) z południowo-wschodniej Polski, w których zostały pilotażowo wdrożone materiały edukacyjne, będące przedmiotem transferu innowacji.

Projekt ReSeCo nawiązywał do europejskich priorytetów w zakresie edukacji i rozwoju społeczno-gospodarczego, $\mathrm{tj}$. wspierania kompetencji kluczowych w przygotowaniu zawodowym i kształceniu przez całe życie. Praktycznym efektem jego realizacji jest transfer innowacji - opracowanych materiałów dydaktycznych, powstałych w wyniku realizacji wcześniejszego projektu unijnego (SeSoKo-fit1), przez zaadaptowanie ich do potrzeb kształcenia dla sektora handlu detalicznego oraz przystosowanie do krajowych wymagań specyficznych dla danego systemu oświaty. Opracowane materiały dydaktyczne dla nauczycieli przedsiębiorczości i in-

\footnotetext{
${ }^{1}$ Informacja (w języku niemieckim) nt. projektu SeSoKo-Fit: http://www.lehrstuhlwipaed.uni-koeln.de/ fileadmin/wiso_fak/wipaed_pilz/Literatur/Projektbeschreibung_SeSoko-Fit.pdf.
} 
nych przedmiotów ekonomicznych zostały wydane w języku angielskim i innych językach narodowych (polski, niemiecki, włoski) w celu upowszechnienia ich w zainteresowanych tymi materiałami placówkach oświatowych. Ponadto w jego ramach dokonano analizy literatury przedmiotu i przeprowadzono wstępne wywiady w zakresie wymagań zainteresowanych stron (partnerów społecznych, szkół) w sektorze detalicznym co do rozwijania kompetencji osobistych i społecznych. W wyniku nawiązania kontaktu z partnerami społecznymi (pracodawcami, organizacjami pracodawców i związkami zawodowymi) przeprowadzono następnie pogłębione wywiady z ich przedstawicielami w odniesieniu do potrzeb i wymagań w sektorze sprzedaży detalicznej w zakresie rozwijania kompetencji osobistych i społecznych oraz przydatności proponowanych materiałów dydaktycznych. W sumie przeprowadzono cztery wywiady pogłębione (2012 r.) z przedstawicielem kadry zarządzającej w międzynarodowej sieci handlowej, z właścicielem sklepu spożywczego, z przedstawicielem Małopolskiej Izby Rzemiosła i Przedsiębiorczości oraz reprezentantem Małopolskiego Stowarzyszenia Kupców i Przedsiębiorców. W artykule przedstawiono więc także ważniejsze wnioski z analizy opinii wymienionych partnerów społecznych.

\section{Przesłanki, cele i przewidywane efekty realizacji projektu ReSeCo}

Podstawową przesłanką realizacji projektu ReSeCo były obserwowane w wielu krajach europejskich problemy z przechodzeniem z kształcenia zawodowego do systemu zatrudnienia (rynku pracy), które wynikają z deficytu kompetencji osobistych i społecznych. Szczególnie dotyczy to niżej wykwalifikowanych młodych ludzi, którzy stoją tuż przed wejściem w życie zawodowe. Głównym celem realizacji projektu była poprawa jakości edukacji w sektorze handlu detalicznego przez rozwój kompetencji osobistych i społecznych. Rozwijanie kompetencji osobistych i społecznych odbywało się w ramach godzin lekcyjnych przedmiotu podstawy przedsiębiorczości i innych przedmiotów zawodowych za pomocą materiałów dydaktycznych dostarczonych nauczycielom. W wyniku wcześniejszej analizy literatury przedmiotu i badań zapotrzebowania środowiska szkolnego w ramach realizacji projektu SeSoKo-fit szczególna uwaga została zwrócona na cztery zagadnienia w ramach szkolenia zawodowego. Było to rozwijanie kompetencji związanych z umiejętnością: pracy zespołowej, świadomego przyjmowania krytyki, zarządzania czasem oraz analizy własnych słabych i mocnych stron w celu lepszej autoprezentacji.

Dobór krajów partnerskich do projektu (Niemcy, Polska, Wielka Brytania i Włochy) pozwolił uzyskać kombinację krajów o odmiennych uwarunkowaniach rozwoju społeczno-gospodarczego i różnych systemach kształcenia zawodowego. Na szczególną uwagę zasługuje tu system polskiego szkolnictwa zawodowego, który w warunkach transformacji gospodarczej ulega głębokim przemianom w wyniku reform organizacyjnych i programowych systemu oświaty, co było przedmiotem szczególnego zainteresowania S. Kurka i T. Rachwała (2012). Transfer innowacji od lidera projektu (Niemcy) odbywał się na trzech różnych poziomach: różnego przedziału wiekowego uczniów, określonej grupy zawodowej i pomiędzy krajami (różne państwa europejskie). Przedmiotem badań i transferu innowacji był sektor detaliczny, który charakteryzuje się różnymi aspektami komunikacji i kontaktu z klientem. Wymagania zawodowe w sektorze handlu są coraz wyższe, szczególnie w związku z kluczowymi kompetencjami społecznymi i osobistymi, co wynika z charakteru tej pracy, wymagającej wysokich umiejętności w zakresie obsługi klienta. Do tych umiejętności należy zaliczyć, za M. Rachwał i T. Rachwałem (2005), m.in. tworzenie kultury organizacyjnej (przedsiębiorstwa lub zespołu obsługi klientów - pracowników tzw. pierwszej linii), która na pierwszym miejscu stawia troskę o klienta, biegłość w kontaktach międzyludzkich, czyli grzeczność, uprzejmość, uczciwość 
opartą na fachowości, umiejętność aktywnego słuchania i tym samym zdobywania informacji, jakie są potrzeby klienta i w jaki sposób można je zaspokoić, analizowanie informacji zwrotnej od klienta, nastawienie na pomoc klientowi, a nie na inne zadania, elastyczny sposób zaspokajania potrzeb klientów, szybkie i sprawne rozpatrywanie reklamacji i umiejętność rozwiązywania konfliktów, który w tym zakresie mogą wystąpić oraz budowanie relacji opartych na partnerstwie, czyli współpracy. Zawód sprzedawcy (handlowca) jest odpowiedni dla transferu innowacji w zakresie edukacji w obrębie krajów Unii Europejskiej, ponieważ wymagania odnośnie tego zawodu są podobne w krajach europejskich, a jego znaczenie jest coraz większe w związku z dynamicznym rozwojem sektora handlu oraz europeizacją, czy wręcz - globalizacją działalności firm tego sektora, czego skutkiem jest wprowadzanie w wielu krajach jednolitych standardów pracy i obsługi klienta.

Efektem długoterminowym realizacji projektu powinno być, przez powszechne zastosowanie w szkole wypracowanych materiałów dydaktycznych, osiągnięcie przez uczniów sukcesu w życiu zawodowym, a przez firmy handlowe - korzyści dzięki lepszemu przygotowaniu potencjalnych pracowników. Nawiązuje to do stanowiska M. Rachwał i T. Rachwała (2005), którzy zauważyli, że w celu utrzymania wysokiego poziomu obsługi klienta w sektorze handlu niezbędne jest kształtowanie tych kluczowych umiejętności już na etapie szkoły ponadgimnazjalnej w ramach edukacji w zakresie przedsiębiorczości, a także w ramach kształcenia ustawicznego w formach pozaszkolnych oraz w rozbudowanym systemie szkoleń pracowników w firmach, jednorazowe szkolenie w tym zakresie nie przynosi bowiem pożądanych efektów. Szkolenia te muszą być systematycznie powtarzane i utrwalane w miejscu pracy w systemie coachingowym i dotyczyć przede wszystkim tzw. miękkich kompetencji, takich jak umiejętność słuchania, rozwiązywania konfliktów, opanowania w kontaktach z klientem, szczególnie w przypadku tzw. trudnych (roszczeniowych) klientów, i empatii. W efekcie, zdaniem tych autorów, budowanie doskonałych relacji z klientem może w istotnym stopniu przyczynić się do podniesienia konkurencyjności przedsiębiorstw oraz konkurencyjności samych uczniów szkół ponadgimnazjalnych, którym ta umiejętność będzie bardzo przydatna w życiu zawodowym. Dlatego też rola tych umiejętności jest nieoceniona w kształceniu w zakresie przedsiębiorczości.

Dla realizacji przyjętych celów określono szczegółowy harmonogram i poszczególne zadania partnerów projektu, które obejmowały, oprócz wspomnianego wyżej przeprowadzenia pogłębionych wywiadów z przedstawicielami partnerów społecznych, także:

- dostosowanie materiałów dydaktycznych (dla czterech modułów kształcenia) do potrzeb krajowego systemu szkolnictwa zawodowego i systemu szkoleń w zakresie handlu detalicznego,

- wdrożenie testujące opracowanych modułów kształcenia w co najmniej trzech szkołach zawodowych lub placówkach szkoleniowych w każdym kraju,

- przeprowadzanie wywiadów z nauczycielami i uczniami w celu oceny procesu wdrażania testującego i przydatności proponowanych materiałów dydaktycznych,

- optymalizację materiałów dydaktycznych na podstawie procesu ewaluacji w fazie wdrożeniowej,

- opracowanie raportów dotyczących procesu realizacji projektu w zakresie uzyskanych wyników na szczeblu krajowym i międzynarodowym,

- upowszechnienie wyników krajowych i międzynarodowych przez raporty i publikacje w języku angielskim oraz językach narodowych, informowanie kluczowych osób w systemie oświaty (m.in. nauczyciele i dyrektorzy szkół oraz centrów kształcenia ustawicznego, przedstawiciele tzw. organów prowadzących, kuratoriów oświaty, ośrodków doskonalenia nauczycieli) dzięki rozpowszechnianiu informacji oraz organizowaniu warsztatów, wspieranie procesów innowacyjnych w systemie szkolnictwa i kształcenia zawodowego. 
Odpowiednie zaplanowanie zadań i pakietów roboczych pozwoliło na efektywną realizację całego projektu ${ }^{2}$.

\section{Rola kompetencji osobistych i społecznych jako składowych postawy przedsiębiorczej w warunkach dekoniunktury gospodarczej}

Kompetencje osobiste i społeczne, takie jak umiejętność analizy własnych słabych i mocnych stron, umiejętność autoprezentacji, umiejętności w zakresie komunikacji interpersonalnej, świadomego przyjmowania krytyki ze strony innych osób, w tym przełożonych i wyciągania z niej wniosków, oraz umiejętność pracy w zespole, zaliczane są do grupy kompetencji podstawowych warunkujących funkcjonowanie każdego człowieka w społeczeństwie i jego efektywne uczestnictwo w życiu społeczno-gospodarczym. Mieszczą się one w obszarze tzw. kompetencji kluczowych europejskiego systemu edukacji (Zalecenie..., 2006; Kompetencje..., 2007). Realizacja projektu i wdrożenie materiałów dydaktycznych do praktyki szkolnej pozwoli na kształtowanie dwóch z nich: inicjatywności i przedsiębiorczości oraz kompetencji społecznych i obywatelskich, a także będzie wspierać osiąganie kompetencji takich jak umiejętność uczenia się i porozumiewania się w języku ojczystym (ryc. 1).

Ryc. 1. Kompetencje kluczowe w europejskim obszarze edukacyjnym w odniesieniu do projektu ReSeCo

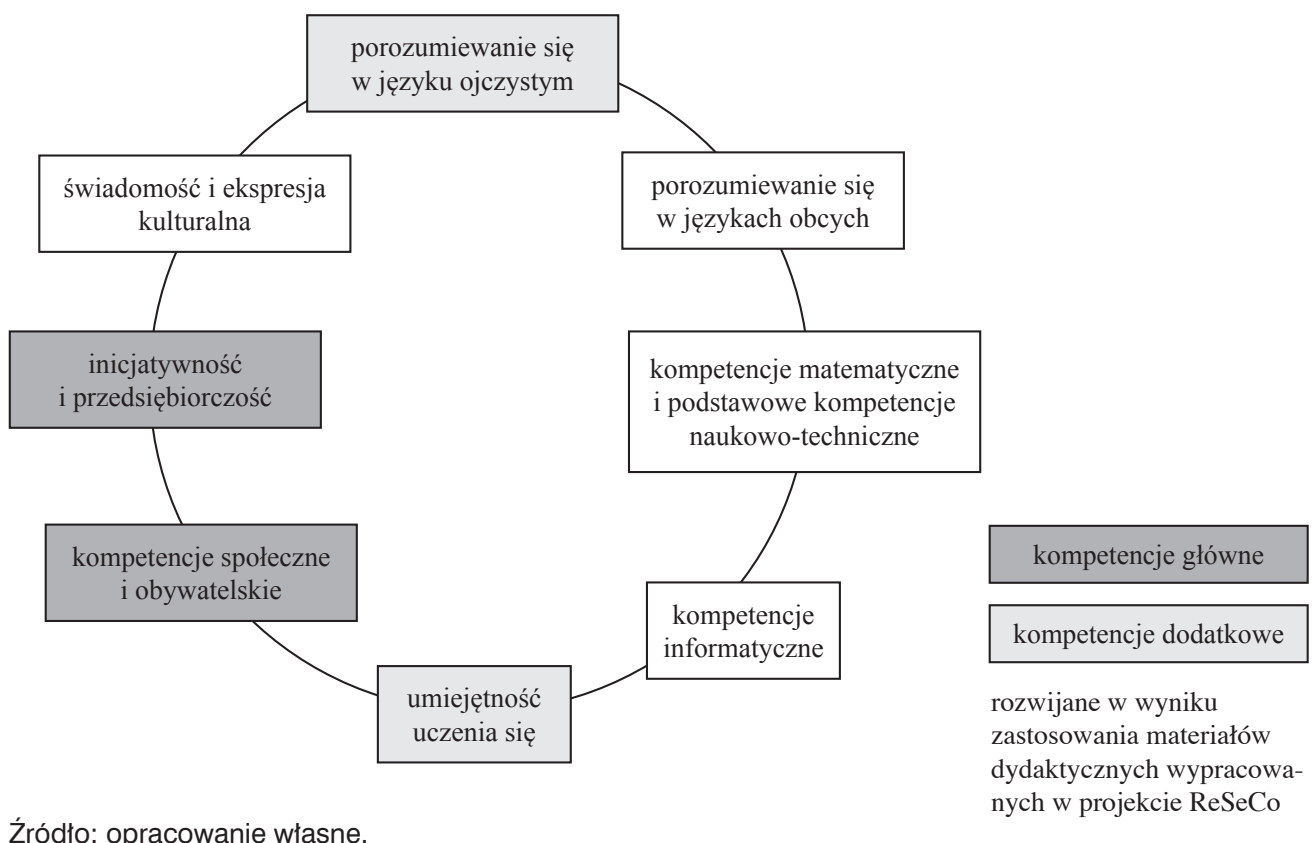

Źródło: opracowanie własne.

\footnotetext{
${ }^{2}$ Więcej o realizacji projektu, w tym informacje o pakietach roboczych, na stronach internetowych UE i partnerów projektu: http://www.adam-europe.eu/adam/project/view.htm?prj=8530\&page=FILES\#. UXzTBbWeN8H; http://www.up.krakow.pl/geo/reseco.html ; http://www.great.uni-koeln.de/16372.html?\&L=1; http://www.southampton.ac.uk/education/research/projects/retail_sector_competencies.page; http://www.unibg.it/struttura/struttura.asp?cerca=dsfc_reseco.
} 
Zgodnie z definicją przyjętą w Unii Europejskiej (Zalecenie..., 2006: 16-17) grupa kompetencji społecznych i obywatelskich to ,kompetencje osobowe, interpersonalne i międzykulturowe obejmujące pełny zakres zachowań przygotowujących osoby do skutecznego i konstruktywnego uczestnictwa w życiu społecznym i zawodowym, szczególnie w społeczeństwach charakteryzujących się coraz większą różnorodnością, a także rozwiązywania konfliktów w razie potrzeby. [...] Kompetencje społeczne są związane z dobrem osobistym i społecznym, które wymaga świadomości, w jaki sposób można zapewnić sobie optymalny poziom zdrowia fizycznego i psychicznego, rozumianego również jako zasób danej osoby i jej rodziny oraz bezpośredniego otoczenia społecznego, a także wiedzy, w jaki sposób może się do tego przyczynić odpowiedni styl życia. Dla powodzenia w kontaktach interpersonalnych i uczestnictwie społecznym niezbędne jest rozumienie zasad postępowania i reguł zachowania ogólnie przyjętych w różnych społeczeństwach i środowiskach (np. w pracy). Równie istotna jest świadomość podstawowych pojęć dotyczących osób, grup, organizacji zawodowych, równości płci i niedyskryminacji, społeczeństwa i kultury. Konieczne jest rozumienie wielokulturowych i społeczno-ekonomicznych wymiarów społeczeństw europejskich, a także wzajemnej interakcji narodowej tożsamości kulturowej i tożsamości europejskiej. Podstawowe umiejętności w zakresie tej kompetencji obejmują zdolność do konstruktywnego porozumiewania się w różnych środowiskach, wykazywania się tolerancją, wyrażania i rozumienia różnych punktów widzenia, negocjowania połączonego ze zdolnością tworzenia klimatu zaufania, a także zdolność do empatii. Osoby powinny być zdolne do radzenia sobie ze stresem i frustracją oraz do wyrażania ich w konstruktywny sposób, a także powinny dokonywać rozróżnienia sfery osobistej i zawodowej. Kompetencja ta opiera się na współpracy, asertywności i prawości. Osoby powinny interesować się rozwojem społeczno-gospodarczym, komunikacją międzykulturową, cenić różnorodność i szanować innych ludzi, a także być przygotowane na pokonywanie uprzedzeń i osiąganie kompromisu".

Natomiast kompetencje określane jako inicjatywność i przedsiębiorczość oznaczają ( $\mathrm{Za}$ lecenie..., 2006: 17-18), ,zdolność osoby do wcielania pomysłów w czyn. Obejmują one kreatywność, innowacyjność i podejmowanie ryzyka, a także zdolność do planowania przedsięwzięć i prowadzenia ich dla osiągnięcia zamierzonych celów. Stanowią one wsparcie dla indywidualnych osób nie tylko w ich codziennym życiu prywatnym i społecznym, ale także w ich miejscu pracy, pomagając im uzyskać świadomość kontekstu ich pracy i zdolność wykorzystywania szans; są podstawą bardziej konkretnych umiejętności i wiedzy potrzebnych tym, którzy podejmują przedsięwzięcia o charakterze społecznym lub handlowym albo w nich uczestniczą. Powinny one obejmować świadomość wartości etycznych i promować dobre zarządzanie. Konieczna wiedza obejmuje zdolność identyfikowania dostępnych możliwości działalności osobistej, zawodowej lub gospodarczej, w tym szerszych zagadnień stanowiących kontekst pracy i życia ludzi, takich jak ogólne rozumienie zasad działania gospodarki, a także szanse i wyzwania stojące przed pracodawcami i organizacjami. Osoby powinny również być świadome zagadnień etycznych związanych z przedsiębiorstwami oraz tego, w jaki sposób mogą one wywoływać pozytywne zmiany, np. przez sprawiedliwy handel lub przedsięwzięcia społeczne. Umiejętności odnoszą się do proaktywnego zarządzania projektami (co obejmuje np. planowanie, organizowanie, zarządzanie, kierowanie i zlecanie zadań, analizowanie, komunikowanie, sporządzanie raportów, ocenę i sprawozdawczość), skutecznej reprezentacji i negocjacji oraz zdolności zarówno pracy indywidualnej, jak i współpracy w zespołach. Niezbędna jest umiejętność oceny i identyfikacji własnych mocnych i słabych stron, a także oceny ryzyka i podejmowania go w uzasadnionych przypadkach. Postawa przedsiębiorcza 
charakteryzuje się inicjatywnością, aktywnością, niezależnością i innowacyjnością zarówno w życiu osobistym i społecznym, jak i w pracy. Obejmuje również motywację i determinację w kierunku realizowania celów, czy to osobistych, czy wspólnych, zarówno prywatnych, jak i w pracy".

Warto również podkreślić, że w niektórych podejściach umiejętności społeczne i w zakresie komunikacji interpersonalnej łączone są ściśle z postawą przedsiębiorczą (Borowiec, Rachwał, 2011; Choinkowska, 2012; Gabała, 2005, Rachwał, 2004a, 2004b, 2006; Osuch, 2011; Wach, 2007) bądź są zaliczane do tzw. kompetencji biznesowych (Berger i in., 2012; Kurek, Rachwał, 2010; Kurek, Rachwał, Szubert, 2012a, 2012b). Są one także przedmiotem głębokiego zainteresowania twórców innych innowacyjnych projektów edukacyjnych w Polsce, takich jak „Krok w przedsiębiorczość" (Rachwał, Ratajski, Zając, 2012; Kilar, Rachwał, Zając, 2012; Dorocki i in., 2012) i ,Jestem przedsiębiorczy” (Świłło, 2012) jako element edukacji w zakresie przedsiębiorczości. Przykładowo, w tym drugim projekcie zakłada się rozwój 11 podstawowych, wyróżnionych na podstawie badań i literatury przedmiotu kompetencji: komunikacja, współpraca, przedsiębiorczość (w węższym rozumieniu, jako zdolność do realizacji wyznaczanych celów biznesowych), elastyczność związana ze zdolnością do reagowania na zmieniającą się rzeczywistość gospodarczą, analiza potrzeb klientów, efektywność (rozumiana jako skuteczność w podejmowanych działaniach), niezależność, związana ze świadomością swoich mocnych i słabych stron, rozwiązywanie problemów, planowanie i organizowanie własnej pracy, kształcenie ustawiczne oraz panowanie nad stresem. Zdaniem I. Świłło (2012: 72) „kompetencje te wzajemnie się uzupełniają i tworzą profil osoby przedsiębiorczej w szerokim rozumieniu tego pojęcia". Analiza definicji kompetencji kluczowych będących przedmiotem projektu ReSeCo zawarta w dokumentach unijnych oraz podejściach różnych autorów wskazuje, że w największym stopniu opracowane materiały dydaktyczne wspierają kompetencje związane z szeroko rozumianą przedsiębiorczością.

Należy w tym miejscu zwrócić uwagę na ogromną rolę przedsiębiorczości w systemie edukacji; roli tej w dużej mierze poświęcono poprzedni, 8 tom czasopisma „Przedsiębiorczość Edukacja”. W artykule wprowadzającym, wskazując na znaczące miejsce przedsiębiorczości w systemie edukacji, Z. Zioło (2012: 11) zwrócił uwagę, że „kształtowanie postaw przedsiębiorczych, przejawiających się w dążeniu do rozwijania aktywności gospodarczej, społecznej, kulturowej czy politycznej, jest niezbędne na wszystkich szczeblach edukacji instytucjonalnej, począwszy od poziomu wczesnoszkolnego przez poziom podstawowy, gimnazjalny, ponadgimnazjalny do kształcenia na poziomie akademickim, a następnie w procesie dokształcania i doskonalenia zawodowego w całym okresie aktywności człowieka na rynku pracy i działalności społecznej”. Jego zdaniem proces ten winien być wspierany przez różnorodne podmioty gospodarcze i instytucje funkcjonujące w otoczeniu społeczno-gospodarczym każdego człowieka. Na potrzebę kształtowania postaw przedsiębiorczych na różnych poziomach edukacji, a także na dużą rolę przedsiębiorczości w rozwoju społeczno-gospodarczym oraz wejściu młodzieży na rynek pracy zwracali uwagę także inni autorzy (por. Cieślik, 2007; Jankowska, Pietrzykowski, 2012; 2013; Juchnowicz, 2005; 2007; Kurek, Rachwał, 2010; 2011; Osuch, 2012; Pietrzykowski, 2011; Piróg, 2012a; 2012b; Surdej, Wach, 2007; Świętek, 2012; Wach, 2007, 2008). Jest to szczególnie ważne w okresie kryzysu gospodarczego, kiedy ograniczenie produkcji wpływa na coraz większe trudności w zakresie znalezienia pracy. Okres dekoniunktury gospodarczej znajduje bowiem swoje odbicie w wysokiej stopie bezrobocia w Polsce i innych krajach Unii Europejskiej, szczególnie wśród młodych ludzi (ryc. 2). 
Ryc. 2. Stopa bezrobocia ogółem oraz wśród ludzi młodych w Unii Europejskiej i wybranych krajach na przełomie 2012 i 2013 r.*

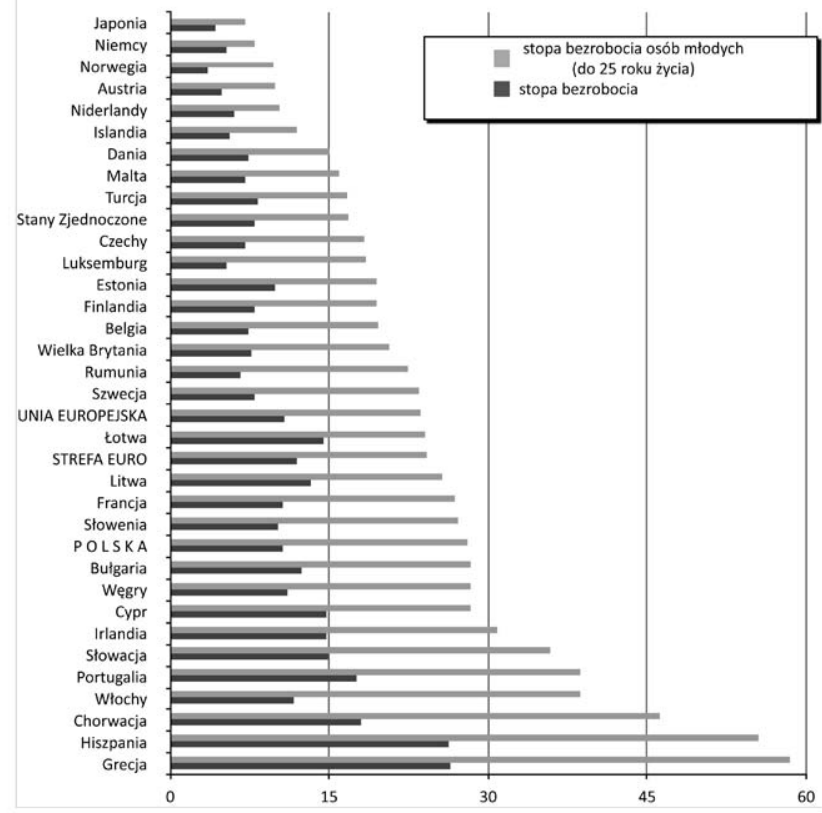

* w zależności od dostępności dane wg stanu na styczeń 2013 lub grudzień 2012 r.

Źródło: opracowanie własne na podstawie danych Eurostatu.

Ryc. 3. Stopa bezrobocia wg wykształcenia w Unii Europejskiej i innych wybranych krajach w 2012 r.

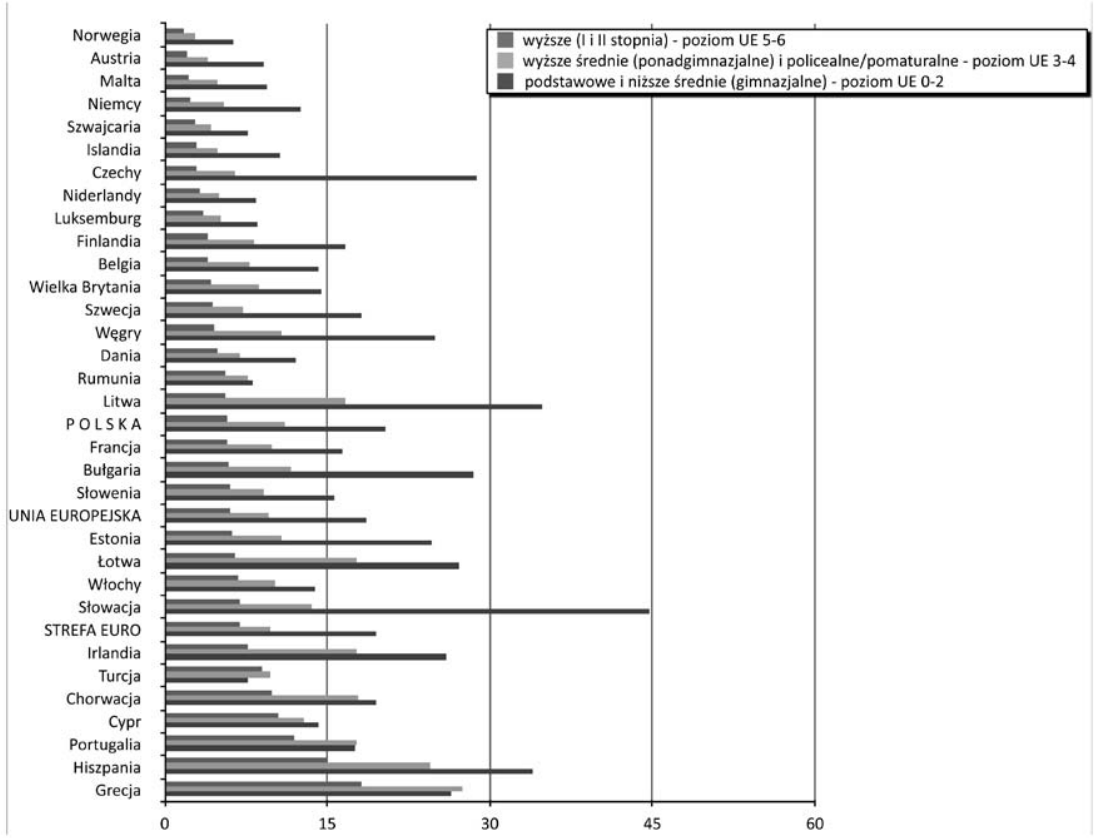

Źródło: opracowanie własne na podstawie danych Eurostatu. 
Warto przy tym zauważyć za D. Piróg (2011a; 2011b; 2012b), że problem trudności w zakresie tranzycji ze systemu szkolnictwa do rynku pracy dotyczy także absolwentów szkół wyższych, choć nadal, mimo tendencji wzrostowej, stopa bezrobocia w Polsce i innych krajach europejskich wśród osób z wyższym wykształceniem jest niższa niż wśród osób z wykształceniem średnim i podstawowym/gimnazjalnym (ryc. 3). Autorka zwraca więc szczególną uwagę na konieczność kształtowania ich kompetencji, nie tylko merytorycznych związanych z wykonywanym w przyszłości zawodem, ale także miękkich, związanych z przedsiębiorczością. Ze stanowiskiem tym zgadzają się inni autorzy, m.in. W. Osuch (2011), podkreślający ogromne znaczenie kompetencji związanych z komunikacją interpersonalną, czy E. Choinkowska (2012), akcentująca rolę pasji, umiejętności podejmowania decyzji, pozytywnego nastawienia i współpracy jako ważnych składowych przedsiębiorczości, odgrywających doniosłą rolę w systemie edukacji.

Należy zwrócić uwagę na fakt, że wychodząc naprzeciw wyzwaniom związanym z dynamicznymi przemianami gospodarczymi oraz problemami rynku pracy w warunkach dekoniunktury gospodarczej, w nawiązaniu do Zalecenia Parlamentu i Rady UE (Zalecenie ..., 2006) w wielu krajach europejskich opracowano specjalne strategie implementacji bądź rozwoju kształcenia w zakresie przedsiębiorczości w kształceniu ogólnym na różnych szczeblach edukacji. Działania takie podjęto w sześciu krajach (Dania, Estonia, Litwa, Niderlandy, Szwecja, Norwegia) i dwóch regionach (część flamandzka Belgii, Walia w Wielkiej Brytanii). Są to najbardziej innowacyjne kraje i regiony północnej Europy. W pozostałych krajach, podobnie jak w Polsce, działania na rzecz szerszego włączenia przedsiębiorczości w system edukacji są z reguły podejmowane jako elementy szerszej strategii rozwoju edukacji lub strategii gospodarczych. Jak bowiem zauważono w raporcie Entrepreneurship Education at School in Europe (Entrepreneurship..., 2012), Europa stoi przed wieloma wyzwaniami, na które może odpowiedzieć, jeśli ma innowacyjnych, dobrze wykształconych i przedsiębiorczych obywateli, którzy mają ducha i ciekawość do myślenia w nowy sposób, a także odwagę, by sprostać i dostosować się do wyzwań stojących przed nimi. Ponadto, dynamicznie zmieniająca się gospodarka, aby być innowacyjna i zdolna do tworzenia nowych miejsc pracy, wymaga większej liczby młodych ludzi, którzy są gotowi i zdolni do podjęcia działalności gospodarczej. A ponieważ edukacja jest kluczem do kształtowania postaw młodych ludzi, ich umiejętności i kultury, ważne jest, żeby nauczanie przedsiębiorczości rozpoczynało się od najmłodszych lat. Kształcenie w zakresie przedsiębiorczości ma kluczowe znaczenie dla kształtowania postaw młodych ludzi, a także zapewnia wiedzę i umiejętności, które są najważniejsze dla rozwoju kultury przedsiębiorczości, będącej podstawą każdej innowacyjnej współczesnej gospodarki.

\section{Opinie partnerów społecznych o roli kompetencji osobistych i społecznych w handlu de- talicznym i edukacji}

W wyniku podjętych działań w pierwszym etapie realizacji projektu - nawiązania kontaktu z partnerami społecznymi (pracodawcami, organizacjami pracodawców i związkami zawodowymi) i przeprowadzenia pogłębionych wywiadów z ich przedstawicielami - uzyskano wyniki pozwalające określić potrzeby i wymagania w sektorze handlu detalicznego w zakresie rozwijania kompetencji osobistych i społecznych. Opinie te dotyczyły czterech kompetencji i zarazem modułów kształcenia, dla których przygotowane zostały materiały dydaktyczne. Były to: umiejętność przyjmowania krytyki, pracy w zespole, zarządzania czasem oraz samooceny mocnych i słabych stron.

W odniesieniu do znaczenia umiejętności świadomego przyjmowania krytyki partnerzy społeczni zwracali uwagę, że bardzo trudno jest nie tylko pracować, ale żyć z ludźmi, którzy 
nie przyjmują konstruktywnej krytyki. Są oni trudni we współpracy i ciężko jest rozwiązywać z nimi problemy pojawiające się w pracy. Partnerzy zwracali uwagę na fakt, że przyjmowanie krytyki jest bardzo ważne, gdyż brak tej umiejętności przenosi się na postawy wobec klientów. Pracownik, który nie jest w stanie przyjąć krytyki swojego szefa, najczęściej obraża klienta i źle go traktuje. Jeden z pracodawców zwracał również uwagę, że w pracy często spotyka się z sytuacjami, w których pracownik się obraża, kiedy - jako właściciel i kierownik - zwraca mu grzecznie uwagę, aby coś wykonał inaczej lub że nie wykonał niektórych zadań. To sprawia, że trudno jest rozwijać relacje między przełożonymi a podwładnymi. Pracownicy przenoszą to zachowanie później na klientów, którzy np. domagają się reklamacji towaru, traktując to jako niesłuszną krytykę ze strony klienta. Rozmówcy podkreślali, iż niestety rozwój tej kompetencji jest bardzo trudny, ponieważ większość ludzi nie chce i nie będzie przyjmować krytyki. Wynika to z psychologii człowieka: nikt nie lubi, gdy ktoś zwraca mu uwagę. Pracodawcy podkreślali również, że kompetencja ta jest bardzo ważna w każdym sektorze gospodarki, nie tylko w handlu. Nie można współpracować z innymi osobami, w tym z przełożonymi, bez tej kompetencji. Trzeba być w stanie przyjmować konstruktywną krytykę w każdej pracy. Krytyka jest niezbędna, zwłaszcza w relacji szef - podwładny lub pomiędzy pracownikami tego samego poziomu. W rozmowach najczęściej przewijał się pogląd, że kompetencja ta jest bardzo ważna, ale trudna do opanowania.

W zakresie umiejętności pracy w zespole partnerzy wskazywali, że w dzisiejszym świecie jest to jedna z kluczowych kompetencji, gdyż, jak powszechnie wiadomo, razem możemy osiągnąć więcej niż osobno. Pracodawcy są więc świadomi ogromnej roli synergii w pracy zespołowej. Zwracał na to też uwagę m.in. S. Covey $(2003,2004)$, który umiejętność tę opisywał jako jedną z podstawowych zasad skutecznego działania i przewodzenia ludziom. Właściciele sklepów detalicznych twierdzili, że w zarządzaniu sklepem praca zespołowa jest najważniejsza. Prowadzenie sklepów składa się z różnorodnych zadań, na sali sprzedaży i w biurze, od rozpakowania dostawy do finalizowania transakcji z klientem przy kasie. Aby te zadania były wykonywane płynnie, potrzeba doskonałej współpracy między sprzedawcami, jak również między sprzedawcami a zespołem zarządzającym. Jest to szczególnie ważne w małych przedsiębiorstwach w sektorze usług i handlu - zwłaszcza w małym sklepie, gdzie kilka osób pracuje na małej powierzchni. Czasami osoby te mają wspólne zadania, a czasami po prostu pracują obok siebie. Ponieważ są w różnych grupach wiekowych i posiadają różne doświadczenia oraz nawyki, mogą pojawić się różne problemy, szczególnie przy pracy na małej przestrzeni. Dlatego współdziałanie w grupie jest bardzo ważne. Jeden z respondentów zwrócił jednak uwagę, że zależy to od organizacji handlu w danym sklepie. Osoba, która pełne osiem godzin siedzi przy biurku/kasie w sklepach wielkopowierzchniowych (hipermarketach), zwykle nie jest w stanie wykazywać tych kompetencji, a jej przełożeni pewnie nie przywiązują do tej kompetencji dużej wagi. Pracodawcy podkreślali też, że kompetencja ta jest bardzo ważna podczas pracy w różnych firmach, nie tylko w sektorze handlu detalicznego, a współcześnie istnieje coraz mniej zawodów, w którym nie trzeba pracować w zespole.

Jeżeli chodzi o umiejętność zarządzania czasem, partnerzy społeczni podkreślali, że jest ona nie tylko potrzebna w pracy, ale też w naszym życiu zawodowym i osobistym. Dobre planowanie sprawia, że życie nie będzie zbyt chaotyczne i można je będzie zaplanować zgodnie z własnymi celami i wartościami. Zaznaczali oni, że w każdym biznesie czas to pieniądz. Bez dobrego zarządzania czasem marnuje się więc zasoby, które są zawsze ograniczone. Dzięki dobrej organizacji czasu można alokować swoje zasoby w sposób najbardziej efektywny i osiągnąć najlepsze możliwe wyniki. Partnerzy zwrócili też uwagę na fakt, że handel detaliczny, zwłaszcza w bezpośredniej obsłudze klienta, jest specyficzny. Kiedy klient pojawia się w sklepie, nie moż- 
na odroczyć jego sprawy na później. Trzeba więc zatrzymać wykonywanie innych czynności, takie jak odbieranie lub układanie towarów, a następnie wrócić do ich wykonywania. Dlatego ważne jest, aby zaplanować czas i mieć zdolność do wykonywania wielu rzeczy na raz. Jeden z pracodawców podkreślał praktyczne aspekty posiadania tej umiejętności przez pracowników dla właściciela firmy. Dla niego jest to bardzo ważna kompetencja, bo jeśli pracownicy jej nie mają, to oznacza, że będzie musiał być jako szef (właściciel) ciągle obecny w miejscu pracy, nakazując im, co mają zrobić w danej chwili. Taka organizacja pracy z punktu widzenia efektywności funkcjonowania przedsiębiorstwa nie ma sensu. Dlatego uważa on, że pracownicy powinni mieć dużą samodzielność, gdyż najlepiej wiedzą, co należy robić w danym momencie, nawet gdy nie ma właściciela w firmie, bo załatwia inne sprawy biznesowe. Ponadto podkreślał on, że ma to znaczenie w zakresie motywowania do pracy: narzucanie pracownikom planu dnia byłoby bardzo złe, bo ludzie poczuliby, że szef nie ma do nich zaufania. Potwierdził to stanowisko inny pracodawca, który podkreślał, że przecież pracownicy w sklepie muszą sami wiedzieć, co i kiedy mają robić, a nie czekać na szefa, który przyjdzie i dokładnie wyznaczy zadania oraz czas ich realizacji. W świetle wypowiedzi partnerów można wnosić, że to jest ważna kompetencja w każdej pracy, nie tylko w handlu detalicznym. Jej znaczenie zależy jednak od charakteru pracy, jak jest ona zorganizowana, np. w sklepach wielkopowierzchniowych (hipermarketach), gdy ktoś pracuje przy kasie, nie ma możliwości wykazać się dobrą organizacją swojego czasu pracy, a więc występuje podobna sytuacja jak w przypadku umiejętności pracy w zespole.

Również czwarta kompetencja uznana została przez partnerów społecznych jako bardzo ważna. Pracodawcy oczekują bowiem od pracowników oceny swoich kompetencji: mocnych i słabych stron. Jest dla nich istotne, jak pracownik ocenia swoje kompetencje, gdyż przyczynia się to do rozwoju pracownika. Bez tych umiejętności pracownicy nie są zwykle bardzo efektywni, nie potrafią ocenić siebie, jak również środowiska, w którym funkcjonują. Ich zdaniem ważne jest, aby dowiedzieć się, jakie są własne możliwości i jak można je wykorzystać w firmie, takiej jak sklep. Jeden z respondentów zwracał uwagę na fakt, że przyjmowanie krytyki i samoocena mają bardzo wiele wspólnego. Osoba, która nie jest w stanie przyjąć konstruktywnej krytyki, z reguły nie jest w stanie przyznać przed sobą, że ma pewne słabości. Dlatego ta ważna kompetencja powinna być rozwijana już od szkoły podstawowej. W szkole zawodowej jest na to trochę za późno, gdyż uczeń przed wyborem profilu szkoły ponadgimnazjalnej (szkoła zawodowa, technikum lub liceum) musi poznać swoje mocne i słabe strony. Zdaniem respondentów jest to kompetencja bardzo przydatna także w życiu codziennym, a zrozumienie własnego potencjału i umiejętność przekazania informacji o swoich własnych mocnych i słabych stronach jest bardzo ważna dla udanej współpracy w grupie. Kompetencja ta może być więc traktowana jako podstawa umiejętności synergicznej pracy zespołowej. Warto jednak podkreślić, że proszeni o hierarchizację wszystkich czterech kompetencji rozmówcy wskazywali, że z punktu widzenia funkcjonowania przedsiębiorstwa samoocena może być uznana za istotną, ale mniej ważną kompetencję w porównaniu z innymi. Jest natomiast niezwykle przydatna w życiu każdego człowieka, w jego osobistym rozwoju, dlatego nie można jej pominąć w toku edukacji szkolnej.

W trakcie wywiadów zebrano także opinie o liczących po kilkadziesiąt stron przygotowywanych materiałach dydaktycznych, obejmujących oprócz szczegółowego scenariusza zajęć także materiały dodatkowe i karty pracy dla uczniów. Zdaniem jednego z rozmówców problematyka ta jest tak ważna, że powinien być nawet odrębny obowiązkowy dla wszystkich przedmiot w szkole mający na celu przygotowanie do życia w społeczeństwie i rozwijanie kompetencji społecznych. Wszyscy partnerzy podkreślali, że proponowane narzędzia dydaktyczne są ciekawe i niosą jasne przesłanie. Zastanawiali się jednak, czy z tych bardzo ciekawych materiałów nauczyciele będą chcieli korzystać i czy będą to robili odpowiednio. Szczególnie spodobały 
się ćwiczenia z zakresu dobrej współpracy w zespole, polegające na wspólnym projektowaniu i budowaniu mostu między ławkami szkolnymi. Budowa mostu jest bardzo odpowiedzialnym i dość skomplikowanym zadaniem, więc rozwija kompetencje zespołu, ponadto most jest także symboliczny: teamwork to budowanie mostów między ludźmi - pozwala lepiej się komunikować, ufać sobie nawzajem. Należy jednak zwrócić uwagę na fakt, że partnerzy społeczni z zagranicy (w wyniku badań partnerów zagranicznych projektu) zaproponowali zamianę mostu na coś bardziej kojarzącego się z handlem (projektowanie i konstruowanie z tektury pudełka do pakowania towaru z zamknięciem). W przypadku materiałów dotyczących samooceny zwrócono uwagę na fakt, że uczniowie mogą się wstydzić pokazywać swoje mocne i słabe strony przy całej klasie. Ponadto, jeden z pracodawców zauważył, że największym problemem współcześnie w Polsce jest brak konieczności posiadania formalnych kwalifikacji do określonego zawodu. Jeśli zostałby przywrócony taki system jak wcześniej, to uczniowie byliby bardziej zmotywowani i bardziej troszczyli się o to, aby rozpoznać swoje mocne i słabe strony oraz wybrać odpowiednią szkołę, przygotowującą do zawodu, który jest zgodny z ich potencjałem i możliwościami. W przeciwnym razie bardzo często wybór profilu szkoły i zawodu jest przypadkowy.

\section{Zakończenie}

Badania przeprowadzone wśród partnerów społecznych wykazały dużą rolę analizowanych kompetencji. Partnerzy wskazali też na wysoką przydatność proponowanych materiałów dydaktycznych w procesie kształcenia z punktu widzenia kształtowania kompetencji społecznych i osobistych przyszłych sprzedawców (handlowców). Ich zdaniem materiały te obejmują cztery, najważniejsze, umiejętności (kompetencje) przydatne nie tylko w sektorze handlu, ale także w każdej innej pracy i życiu osobistym. Dlatego można je wykorzystywać także w szkołach o innym profilu, a nawet na lekcjach przedsiębiorczości w liceach ogólnokształcących. Respondenci przedstawili propozycje niewielkich zmian w materiałach dydaktycznych, niezmieniających istotnych założeń każdego z czterech modułów kształcenia.

Faza wdrożeniowa (testowa) w szkołach, której zakończenie planowane było na początek II kwartału 2013 r. pozwoliła na dalszą optymalizację materiałów pod kątem potrzeb szkół zawodowych kształcących dla sektora handlu detalicznego. Już jednak pierwszy etap realizacji projektu wskazał na wysoką aktualność i potrzebę realizacji tego typu działań w polskiej szkole.

\section{Literatura}

Berger, S., Canning, R., Dolan, M., Kurek, S., Pilz, M., Rachwał, T. (2012). Curriculum-making in prevocational education in the lower secondary school: A regional comparative analysis within Europe. Journal of Curriculum Studies, 44 (5), 679-701.

Borowiec, M., Rachwał, T. (2011). Kształtowanie postaw przedsiębiorczych na lekcjach geografii wyzwaniem edukacyjnym w procesach globalizacji. Przedsiębiorczość - Edukacja, 7, 321-332.

Choinkowska, E. (2012). Budowanie postaw przedsiębiorczych w pracy pedagogicznej przez oddziaływanie psychologiczne. Przedsiębiorczość - Edukacja, 8, 127-136.

Cieślik, J. (2007). Kształcenie w zakresie przedsiębiorczości na poziomie akademickim. W: P. Wachowiak, M. Dabrowski, B. Majewski (red.), Kształtowanie postaw przedsiębiorczych a edukacja ekonomiczna. Warszawa: Fundacja Promocji i Akredytacji Kierunków Ekonomicznych, 71-80.

Covey, S.R. (2003). 7 nawyków skutecznego działania. Poznań: Rebis.

Covey, S.R. (2004). Zasady skutecznego przywództwa, Poznań: Rebis. 
Czapliński, P. (2011). Funkcjonowanie przemysłu przetwórstwa rybnego w Polsce w okresie kryzysu gospodarczego. Prace Komisji Geografii Przemystu Polskiego Towarzystwa Geograficznego, 17, 114-128.

Dorocki, S. (2011). Wpływ kryzysu gospodarczego na przemiany struktur regionalnych Francji. Prace Komisji Geografii Przemystu Polskiego Towarzystwa Geograficznego, 17, 67-86.

Dorocki, S., Kilar, W., Rachwał, T., Świętek, A., Zdon-Korzeniowska, M. (2012). Biznesplan krok po kroku. Poradnik dla uczniów i uczennic. III część produktu finalnego. Warszawa: wydawnictwo Nowa Era.

Entrepreneurship Education at School in Europe. National Strategies, Curricula and Learning Outcomes (2012). Education, Audiovisual and Culture Executive Agency. Brussels: Eurydice.

Gabała, J. (2005). Kształtowanie postaw przedsiębiorczych uczniów. Przedsiębiorczość - Edukacja, 1, $145-152$.

Jankowska, B., Pietrzykowski, M. (2012). Postawy proprzedsiębiorcze studentów a profil kształcenia Polska na tle innych krajów. Przegląd Organizacji, 8, 28-32.

Jankowska, B., Pietrzykowski, M. (2013). Pro-entrepreneurial attitudes of students in relation to their educational profile: Poland against the background of other countries. Interdisciplinary Studies Journal, 2 (4), 83-102.

Juchnowicz, K. (2007). Polityka edukacyjna wobec potrzeb rynku pracy. W: P. Wachowiak, M. Dabrowski, B. Majewski (red.), Kształtowanie postaw przedsiębiorczych a edukacja ekonomiczna. Warszawa: Fundacja Promocji i Akredytacji Kierunków Ekonomicznych, 40-46.

Juchnowicz, M. (2005). Uwagi dotyczące realizacji przedmiotu podstawy przedsiębiorczości. Przedsiębiorczość - Edukacja, 1, 189-193.

Kilar, W. (2011). Wpływ kryzysu na funkcjonowanie korporacji Panasonic. Prace Komisji Geografii Przemystu Polskiego Towarzystwa Geograficznego, 17, 187-196.

Kilar, W., Rachwał, T., Zając, M. (2012). Poradnik metodyczny dla nauczycieli i nauczycielek. II część produktu finalnego. Warszawa: wydawnictwo Nowa Era.

Kitowski, J. (2009). Influence of Global Economic Crisis on Operation of Special Economic Zones in Poland. Geopolitical Studies, 15, 241-267.

Kitowski, J. (2011). Wpływ kryzysu finansowego i gospodarczego na efekty funkcjonowania specjalnych stref ekonomicznych w Polsce. W: B. Namyślak (red.), Przeksztatcenia regionalnych struktur funkcjonalno-przestrzennych. Współczesne kierunki przemian społeczno-ekonomicznych, Rozprawy Naukowe Instytutu Geografii i Rozwoju Regionalnego, 19, Wrocław, 23-39.

Kompetencje kluczowe w uczeniu się przez całe życie. Europejskie Ramy Odniesienia. (2007). Luxembourg: Urząd Oficjalnych Publikacji Wspólnot Europejskich.

Kurek, S., Rachwał, T. (2010). The Role of Business Education in the Development of Entrepreneurship in the Member States of the European Union, Europa XXI, 19, 127-142.

Kurek, S., Rachwał, T. (2011). Development of entrepreneurship in ageing populations of The European Union, Procedia. Social and Behavioral Sciences, 19 (2011), 397-405.

Kurek, S., Rachwał, T. (2012). Vocational Education and Training in Poland During Economic Transition. In: M. Pilz (ed.), The Future of Vocational Education and Training in a Changing World. Wiesbaden: Springer, 321-340.

Kurek, S., Rachwał, T., Szubert, M. (2012a). Business Competencies in Polish School Curricula: Opinions of Teachers and Social Partners. In: M. Pilz, S. Berger, R. Canning (eds), Fit for Business. PreVocational Education in European Schools, Wiesbaden: Springer, 61-88.

Kurek, S., Rachwał, T., Szubert, M. (2012b). Kształtowanie kompetencji biznesowych uczniów gimnazjum w świetle opinii nauczycieli na podstawie wyników badań prowadzonych w ramach europejskiego projektu FIFOBI. Przedsiębiorczość - Edukacja, 8, 24-36.

Nowak, P. (2011). Funkcjonowanie sektora motoryzacyjnego w okresie kryzysu w latach 2008-2009. Prace Komisji Geografii Przemystu Polskiego Towarzystwa Geograficznego, 17, 177-186.

Osuch, W. (2011). Kompetencje w zakresie komunikacji interpersonalnej w dobie postępujących procesów globalizacji. Przedsiębiorczość - Edukacja, 7, 177-186.

Osuch, W. (2012). Ocena wykształcenia kompetencji przedmiotowych z geografii społeczno-gospodarczej a wybrane aspekty innowacyjności w edukacji i kształceniu nauczycieli. Annales Universitatis Paedagogicae Cracoviensis Studia Geographica, 3, 122-137. 
Pietrzykowski, M. (2011). Entrepreneurship in Higher Education - the case of Poland. In: M. Dabić, M. Pietrzykowski (eds), Fostering Education in Entrepreneurship, Poznań: Bogucki Wydawnictwo Naukowe, 113-128.

Piróg, D. (2011a). Usługi edukacyjne na poziomie akademickim w kontekście wymagań rynku pracy, Prace Komisji Geografii Przemystu Polskiego Towarzystwa Geograficznego, 18, 23-36.

Piróg, D. (2011b). Graduates of geographical studies on the labour market in the process of transformation in higher education. Prace i Studia Geograficzne, 48, Prace Instytutu Geografii UJK, 18, 161-172.

Piróg, D. (2012a). Changes to the conception of geography curricula within university education in Poland in the 21 st century in the face of labour market challenges. European Journal of Geography, $3(2), 24-41$.

Piróg, D. (2012b). Methods for efficiency improvement of geographical studies within the scope of procurement of work by graduates exemplified by solutions applied in Great Britain and in Germany. In: B. Wójtowicz (ed), Natural sciences in educational systems of European countries in the 21 st century. Kraków: Wydawnictwo DEHON, 129-141.

Rachwał, M., Rachwał, T. (2005), Rola kształcenia umiejętności obsługi klienta na lekcjach podstaw przedsiębiorczości. Przedsiębiorczość - Edukacja, 1, 221-226.

Rachwał, T. (2004a). Podstawy przedsiębiorczości. Słownik, Warszawa: wydawnictwo Nowa Era.

Rachwał, T. (2004b). Cele i treści kształcenia przedsiębiorczości w szkołach ponadgimnazjalnych. W: J. Brdulak, M. Kulikowski (red.), Przedsiębiorczość stymulatorem rozwoju gospodarczego, Warszawa: Instytut Wiedzy, 263-270.

Rachwał, T. (2006). Kształtowanie postaw przedsiębiorczych w edukacji szkolnej. W: B. Muchacka (red.), Szkoła w nauce i praktyce edukacyjnej, t. II, Kraków: Oficyna Wydawnicza „Impuls”, Akademia Pedagogiczna w Krakowie, 427-434.

Rachwał, T., (2011). Wpływ kryzysu na zmiany produkcji przemysłowej w Polsce. Prace Komisji Geografii Przemystu Polskiego Towarzystwa Geograficznego, 17, 99-113.

Rachwał, T., Zdon-Korzeniowska, M. (2011). Turystyka w warunkach światowego kryzysu gospodarczego. Prace Komisji Geografii Przemystu Polskiego Towarzystwa Geograficznego, 18, 116-128.

Rachwał, T., Ratajski, P., Zając M. (2012). Innowacyjna Strategia Kształcenia „Krok w przedsiębiorczość”. I część produktu finalnego. Warszawa: wydawnictwo Nowa Era.

Rettinger, R., Staszak, P. (2011), Wpływ kryzysu na wielkość pasażerskiego ruchu lotniczego na świecie na podstawie wybranych przykładów. Prace Komisji Geografii Przemysłu Polskiego Towarzystwa Geograficznego, 18, 129-138.

Šerý, O. (2011). The impact of economic crisis on regions dominated by motor vehicles industry (the case of Vysočina Region). Prace Komisji Geografii Przemystu Polskiego Towarzystwa Geograficznego, $17,155-163$.

Surdej, A., Wach, K. (2007). Entrepreneurship as the Challenge for Polish Economy in the 21st Century. Miskolc University - Faculty of Economics Conference Proceedings. Pozyskane z: http://dx.doi. org/10.2139/ssrn.1113531.

Świętek, A. (2012). Oczekiwania a realia wejścia ludzi młodych na rynek pracy jako wyzwanie dla edukacji z przedsiębiorczości. Przedsiębiorczość - Edukacja, 8, 137-154.

Świłło, I. (2012), „Jestem przedsiębiorczy - kształtowanie postaw przedsiębiorczych wśród młodzieży z wykorzystaniem innowacyjnych technik i narzędzi”. Prezentacja projektu, Przedsiębiorczość Edukacja, 7, 64-70.

Uliszak, R. (2011). Przejawy kryzysu we współczesnym rolnictwie. Prace Komisji Geografii Przemystu Polskiego Towarzystwa Geograficznego, 18, 101-115.

Wach, K. (2007). Kształtowanie postaw przedsiębiorczych w programach nauczania. Stan obecny i proponowane kierunki zmian. W: P. Wachowiak, M. Dabrowski, B. Majewski (red.), Kształtowanie postaw przedsiębiorczych a edukacja ekonomiczna. Warszawa: Fundacja Promocji i Akredytacji Kierunków Ekonomicznych, 120-127.

Wach, K. (2008). Entrepreneurship Education in Poland. ERENET Profile, vol. III, no. 3 (11), 36-44.

Wójtowicz, M. (2011). Wpływ światowego kryzysu gospodarczego na brazylijski i meksykański przemysł samochodowy. Prace Komisji Geografii Przemystu Polskiego Towarzystwa Geograficznego, 17, 
Zalecenie Parlamentu Europejskiego i Rady z dnia 18 grudnia 2006 r. w sprawie kompetencji kluczowych w procesie uczenia się przez całe życie (2006/962/WE).

Zioło, Z. (2011). Wpływ światowego kryzysu na tempo wzrostu gospodarki i światowych korporacji. Prace Komisji Geografii Przemystu Polskiego Towarzystwa Geograficznego, 17, 9-32.

Zioło, Z. (2012). Miejsce przedsiębiorczości w edukacji. Przedsiębiorczość - Edukacja, 8, 10-23.

Wioletta Kilar, dr, Uniwersytet Pedagogiczny im. Komisji Edukacji Narodowej w Krakowie, Instytut Geografii, Zakład Przedsiębiorczości i Gospodarki Przestrzennej.

Geograf ekonomiczny. Adiunkt w Zakładzie Przedsiębiorczości i Gospodarki Przestrzennej Instytutu Geografii Uniwersytetu Pedagogicznego w Krakowie, Sekretarz Rady Redakcyjnej czasopisma „Prace Komisji Geografii Przemysłu Polskiego Towarzystwa Geograficznego". Posiada znaczne doświadczenie jako nauczyciel geografii i podstaw przedsiębiorczości, które zdobyła pracując w kilku ponadgimnazjalnych szkołach krakowskich. Jej zainteresowania badawcze ukierunkowane są przede wszystkim na procesy kształtowania się i funkcjonowania ponadnarodowych korporacji, globalizacji, przemian struktur przestrzennych przemysłu oraz problematykę nauczania przedsiębiorczości i geografii w szkole. Jest autorem i współautorem licznych publikacji z zakresu geografii społeczno-ekonomicznej i przedsiębiorczości oraz wielu materiałów dydaktycznych, edukacyjnych i ekspertyz.

Wioletta Kilar, PhD, Pedagogical University of Cracow, Institute of Geography, Department of Entrepreneurship and Spatial Management.

An economic geographer. Lecturer at Department of Entrepreneurship and Spatial Management of Institute of Geography of the Pedagogical University of Cracow. Secretary of the Editorial Board of the Studies of the Industrial Geography Commission of the Polish Geographical Society. Possesses considerable experience as a teacher of geography and basics of entrepreneurship, having been employed at several secondary schools in Krakow. Research interests focus primarily on the processes of formation and operation of multinational corporations, globalization, transformation of spatial structures of industry, and issues of entrepreneurship and geography education at school. Author of numerous publications in the area of socio-economic geography and entrepreneurship, and various teaching and educational materials and expertise.

Sławomir Kurek, dr hab., profesor Uniwersytetu Pedagogicznego, Uniwersytet Pedagogiczny im. Komisji Edukacji Narodowej w Krakowie, Instytut Geografii, Zakład Geografii Społeczno-Ekonomicznej.

Geograf społeczno-ekonomiczny. Członek Komitetu Nauk Demograficznych PAN. Pełni m.in. funkcję zastępcy dyrektora Instytutu Geografii ds. Nauki i Współpracy Zagranicznej, kierownika Studiów Doktoranckich z Geografii oraz redaktora naczelnego czasopisma „Annales Universitatis Paedagogicae Cracoviensis, Studia Geographica”. Jego zainteresowania badawcze skupiają się przede wszystkim na problematyce przemian struktur społeczno-demograficznych Polski i Europy, procesów suburbanizacji w obszarach metropolitalnych oraz edukacji w zakresie przedsiębiorczości.

Stawomir Kurek, associate professor at the Pedagogical University of Cracow, Institute of Geography, Department of Socio-Economic Geography.

A socio-economic geographer. Member of the Committee on Demographic Studies of the Polish Academy of Sciences. He is, among other activities, the Deputy Head for Research and International Relations of Institute of Geography, Head of Doctoral Studies in geography at the Pedagogical University, and Editor in Chief of Annales Universitatis Paedagogicae Cracoviensis, Studia Geographica. Research interests focus primarily on the issue of changes of the socio-demographic structures in Poland and Europe, suburbanisation processes in metropolitan areas, as well as entrepreneurship education. 
Tomasz Rachwal, dr, Uniwersytet Pedagogiczny im. Komisji Edukacji Narodowej w Krakowie, Instytut Geografii, Zakład Przedsiębiorczości i Gospodarki Przestrzennej.

Geograf ekonomiczny, członek Krajowej Rady Przedsiębiorczości. Pełni m.in. funkcję Kierownika Zakładu Przedsiębiorczości i Gospodarki Przestrzennej Instytutu Geografii Uniwersytetu Pedagogicznego w Krakowie, Sekretarza Naukowego Komisji Geografii Przemysłu Polskiego Towarzystwa Geograficznego, Zastępcy Redaktora Naczelnego czasopism „Prace Komisji Geografii Przemysłu Polskiego Towarzystwa Geograficznego”, „Przedsiębiorczość - Edukacja” oraz „Annales Universitatis Paedagogicae Cracoviensis Studia Geographica". Jego zainteresowania badawcze skupiają się przede wszystkim na problematyce przemian struktur przestrzennych przemysłu, funkcjonowania różnych branż działalności gospodarczej, restrukturyzacji przedsiębiorstw oraz roli przedsiębiorczości w rozwoju układów przestrzennych oraz edukacji w zakresie przedsiębiorczości.

Tomasz Rachwal, PhD, Pedagogical University of Cracow, Institute of Geography, Department of Entrepreneurship and Spatial Management.

An economic geographer. Member of the National Council for Entrepreneurship. Head of Department of Entrepreneurship and Spatial Management of Institute of Geography of the Pedagogical University of Cracow, Scientific Secretary of the Industrial Geography Committee of the Polish Geographical Society, Deputy Editor in Chief of the following journals: Studies of the Industrial Geography Commission of the Polish Geographical Society, Entrepreneurship -Education and Annales Universitatis Paedagogicae Cracoviensis Studies Geographica. Research interests focus primarily on the issue of change of spatial structures of industry, the functioning of various branches of industrial activity, corporate restructuring and the role of entrepreneurship in the development of spatial systems and entrepreneurship education.

Adres/Address: Uniwersytet Pedagogiczny

Instytut Geografii, Zakład Przedsiębiorczości i Gospodarki Przestrzennej

ul. Podchorążych 2, 30-084 Kraków, Polska

e-mail: W.Kilar@up.krakow.pl, T.Rachwal@up.krakow.pl, sgkurek@up.krakow.pl

Publikacja powstała w ramach projektu „Retail Sector Competencies: Developing self and social competencies in vocational training for the retail sector (ReSeCo) / Kompetencje Sektora Handlu Detalicznego - kształtowanie kompetencji osobistych i społecznych w szkolnictwie zawodowym dla sektora handlu detalicznego" realizowanego przy wsparciu finansowym Komisji Europejskiej w ramach Programu „Uczenie się przez całe życie” (Lifelong Learning Programme), numer projektu DE/11/LLP-LdV/ TOI/147405. Publikacja odzwierciedla jedynie stanowisko ich autorów i Komisja Europejska nie ponosi odpowiedzialności za umieszczoną w nich zawartość merytoryczną.
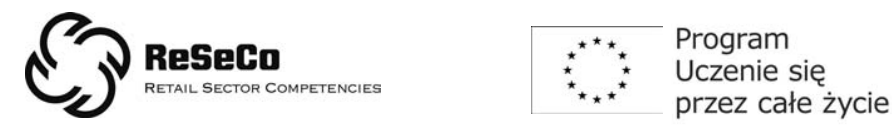